\title{
TATA KELOLA TEKNOLOGI INFORMASI DI UNIVERSITAS PQR BERBASIS FRAMEWORK COBIT 4.1
}

\author{
Iskandar Ikbal., S.T., M.Kom ${ }^{1}$ \\ ${ }^{1}$ Teknik Informatika FTIK UNIKOM \\ ikbal80.id@gmail.com
}

\begin{abstract}
ABSTRAK
UNIVERSITAS PQR adalah salah satu Perguruan Tinggi (PT) swasta yang ada di Indonesia, telah mengimplementasikan Teknologi Informasi (TI) dalam mendukung dan mempermudah jalannya operasional organisasi / institusinya. Namun pada kenyataannya implementasi dan pemanfaatan TI di UNIVERSITAS PQR masih belum terkelola dengan baik dilihat dari beberapa indikator yaitu perencanaan dan pengembangan strategis TI yang masih dilakukan secara sporadis, nilai tambah dari implementasi dan pemanfaatan TI masih sangat kecil, penggunaan sumber daya TI belum menunjukkan kepada tingkat efisiensi dan efektivitas, serta dari sisi keamanan dan risiko TI dirasa kurang begitu mendapat perhatian. Tujuan yang ingin dicapai dalam penelitian ini adalah untuk mendapatkan bentuk tata kelola TI yang sesuai dengan UNIVERSITAS PQR.

Dari hasil penilaian proses-proses TI terpilih sebanyak tujuh belas proses secara mayoritas tingkat kematangan tata kelola TI UNIVERSITAS PQR saat ini berada pada level satu atau Ad Hoc/Initial. Target tingkat kematangan tata kelola TI yang ingin dicapai adalah pada level tiga atau Defined.

Untuk mencapai target tingkat kematangan yang diinginkan, dapat direkomendasikan lima hal yaitu restrukturisasi struktur internal divisi IT, mendokumentasikan kebijakan dan standard operating prosedur (SOP), melaksanakan program awareness, mengadakan pelatihan dan pendidikan terhadap SDM TI, dan memanfaatkan best practice sebagai acuan dalam tata kelola TI.
\end{abstract}

Kata Kunci : Tata Kelola, Teknologi Informasi, COBIT.

\section{PENDAHULUAN}

Penerapan Teknologi Informasi (TI) pada suatu organisasi / institusi membutuhkan biaya yang cukup besar dengan kemungkinan resiko kegagalan yang cukup besar. Tetapi disaat yang bersamaan, penerapan TI juga memberikan peluang atau kesempatan untuk menjadikan pentransformasian dan produktifitas bisnis yang sedang dan atau telah berjalan. Penerapan TI tidak selalu sama dengan pertumbuhan atau perkembangan organisasi/institusi, tetapi dapat juga mendukung suatu organisasi /institusi untuk tetap bertahan di tengah persaingan [1]. 
Penelitian menunjukkan bahwa implementasi TI sudah berpindah dari isu teknologi menjadi isu manajemen dan pengelolaan. TI harus dikelola selayaknya aset organisasi / institusi lainnya. Penerapan TI di organisasi / institusi dapat dilakukan dengan baik apabila ditunjang dengan suatu tatakelola TI dari mulai perencanaan sampai implementasinya.

Tatakelola TI adalah suatu struktur hubungan dan proses untuk mengatur dan mengontrol organisasi / institusi yang bertujuan untuk mencapai tujuan organisasi / institusi yang telah ditetapkan dengan pertambahan nilai dengan tetap menyeimbangkan risiko-risiko dengan nilai yang didapatkan dari penerapan TI dan proses-prosesnya [2].

Tata kelola TI bukan bidang yang terpisah dari pengelolaan organisasi / institusi, melainkan merupakan komponen pengelolaan organisasi / institusi secara keseluruhan beserta tanggung jawab utamanya.

UNIVERSITAS PQR merupakan salah satu Perguruan Tinggi (PT) swasta yang ada di Indonesia telah menerapkan TI dalam mendukung dan mempermudah jalannya operasional organisasi / institusinya. Dimana UNIVERSITAS PQR berkeinginan, dalam beberapa tahun kedepan secara global dapat menjadi organisasi / institusi PT unggulan dan terpandang.

Namun pada kenyataannya implementasi dan pemanfaatan TI di UNIVERSITAS PQR masih belum terkelola dengan baik. Ini dapat dijelaskan dengan beberapa bukti dari survei lapangan yang dilakukan, antara lain:

1. Perencanaan dan pengembangan strategis TI dilakukan secara sporadis, yang dilakukan hanya untuk mengantisipasi perkembangan trend TI tertentu saja, yang terkadang menyebabkan terjadinya ketidak selarasan hubungan antara TI dan tujuan strategis yang telah ditetapkan.

2. Nilai tambah dari implementasi dan pemanfaatan TI memang telah dirasakan tetapi masih sangat kecil prosentasenya dibandingkan dengan sumber daya TI yang tersedia, dimana TI hanya dipandang sebagai support system dan belum menjadi enabler system yang sesungguhnya.

3. Penggunaan sumber daya TI belum menunjukkan kepada tingkat efisiensi dan efektivitas, penyebab utamanya adalah belum adanya struktur organisasi TI yang sepenuhnya berperan dan memiliki tanggungjawab dalam mengatur penggunaan sumber daya TI yang ada.

4. Dari sisi keamanan dan risiko TI dirasa kurang begitu mendapat perhatian, karena tidak ada satupun Standard Operating Procedure (SOP) yang jelas untuk proses implementasi, pengembangan dan pengelolaan infrastruktur dan sumber daya TI.

Bukti-bukti tesebut menunjukkan bahwa pengelolaan TI di UNIVERSITAS PQR belum berjalan dengan baik. Oleh karena itu, agar implementasi dan pemanfaatan sumber daya TI dan SDM-nya dapat terkelola dengan efektif dan efisien, maka diperlukan perancangan tata kelola TI yang mengacu kepada standar kerangka kerja / framework tata kelola TI yang telah diakui oleh dunia intenasional. Pada perancangan tata kelola TI UNIVERSITAS PQR ini dipilih standar kerangka kerja / framework COBIT, dengan alasan bahwa COBIT, merupakan standar framework IT Governance yang telah mendapatkan pengakuan yang baik dalam hal kapabiltias dan keluasan cakupan pengelolaan serta detail proses-prosesnya dibandingkan dengan standarstandar lainnya. Namun yang paling penting adalah ruang lingkup business goals COBIT dapat merepresentasikan tujuan strategis UNIVERSITAS PQR. 


\section{KAJIAN PUSTAKA \\ II.1. Tata Kelola Teknologi Informasi (TI)[2]}

Masalah tata kelola teknologi informasi (TI) pada sebuah organisasi / institusi menyangkut beberapa hal yang perlu dipahami agar dapat membantu menganalisis dan pengembangan solusi. Beberapa hal yang akan mendasari untuk membantu pencapaian tujuan tersebut dan yang menjadi penekanan disini adalah:

1. Pemahaman mengenai tata kelola TI.

2. Kerangka Kerja (Framework) yang memberikan panduan dalam pengembangan tata kelola TI.

3. Pengukuran, untuk membantu menilai kondisi tata kelola yang ada sebagai as is dan kemudian dapat digunakan sebagai dasar untuk penetapan target tingkat kematangan tata kelola TI yang diinginkan to be.

Definisi tentang tata kelola TI yang diambil dari IT Governance Institute adalah sebagai berikut :

"Tata kelola TI didefinisikan sebagai tanggungjawab eksekutif dan dewan direktur, dan terdiri atas kepemimpinan, struktur organisasi serta proses-proses yang memastikan TI organisasi / institusi mendukung dan mengembangkan tujuan dan strategi organisasi / institusi” [3].

\section{II.2. Framework COBIT 4.1 [3]}

Pembahasan framework COBIT 4.1 ini, dimaksudkan untuk mendapatkan pemahaman mengenai tujuan dan keuntungan yang didapat, dengan diimplementasikannya framework COBIT 4.1 dalam mendukung tata kelola TI. Hal ini karena penggunaan COBIT 4.1 dalam mendukung tata kelola TI, akan dapat memberikan sebuah framework untuk memastikan agar:

1. TI selaras dengan bisnis.

2. TI memungkinkan bisnis dan memaksimalkan benefit.

3. Sumberdaya TI digunakan dengan tanggungjawab.

4. Resiko TI dikelola dengan tepat.

COBIT 4.1 mengintegrasikan best practice terhadap TI dan menyediakan kerangka kerja/framework untuk tata kelola TI, yang dapat membantu pemahaman dan pengelolaan TI serta memperoleh keuntungan yang berkaitan dengan TI. Dengan demikian implementasi COBIT 4.1 sebagai framework tata kelola TI akan dapat memberikan keuntungan:

1. Penyelarasan yang lebih baik, berdasarkan pada fokus bisnis.

2. Memberikan pemahaman kepada pihak manajemen tentang hal yang dapat dilakukan TI.

3. Tanggungjawab dan kepemilikan yang jelas didasarkan pada orientasi proses.

4. Dapat diterima secara umum dengan pihak ketiga dan pembuat aturan.

5. Berbagi pemahaman diantara pihak yang berkepentingan, didasarkan pada sebuah bahasa umum.

6. Pemenuhan kebutuhan COSO (Committee of Sponsoring Organisations of the Treadway Commision) untuk lingkungan kendali TI.

Dalam memahami framework COBIT 4.1, perlu diketahui mengenai karakteristik utama dimana framework COBIT 4.1 dibuat, serta prinsip yang mendasarinya. Adapun 
karakteristik utama framework COBIT 4.1 adalah business-focused, process-oriented, controls-based dan measurement-driven, sedangkan prinsip yang mendasarinya adalah [3]:

"Untuk memberikan informasi yang diperlukan organisasi / institusi guna mencapai obyektifnya, organisasi / institusi perlu mengelola dan mengendalikan sumberdaya TI dengan menggunakan kumpulan proses-proses yang terstruktur untuk memberikan layanan informasi yang diperlukan."

\section{II.3. Alur Model Framework COBIT 4.1 [3]}

Framework COBIT 4.1, mengikat kebutuhan bisnis untuk informasi dan tata kelola, pada obyektif fungsi layanan TI. Model proses COBIT 4.1 memungkinkan IT activities dan sumberdaya yang mendukungnya dikelola dan dikontrol dengan tepat berdasarkan COBIT's control objectives, serta diselaraskan dan dimonitor menggunakan COBIT's KGI and KPI metrics, sebagaimana gambar 2.1.

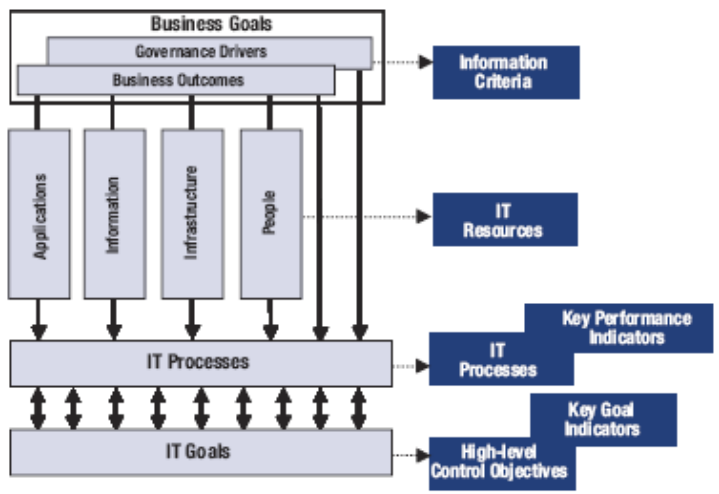

Gambar 2.1. COBIT 4.1 Management, Control, Alignment and Monitoring [3]

Secara lebih terinci keseluruhan framework COBIT 4.1 ditunjukkan sebagaimana gambar 2.2, dengan COBIT's process model dari empat domain mengandung 34 proses generik, yang mengelola IT resources untuk memberikan informasi pada bisnis sesuai dengan kebutuhan bisnis dan tata kelola TI. 


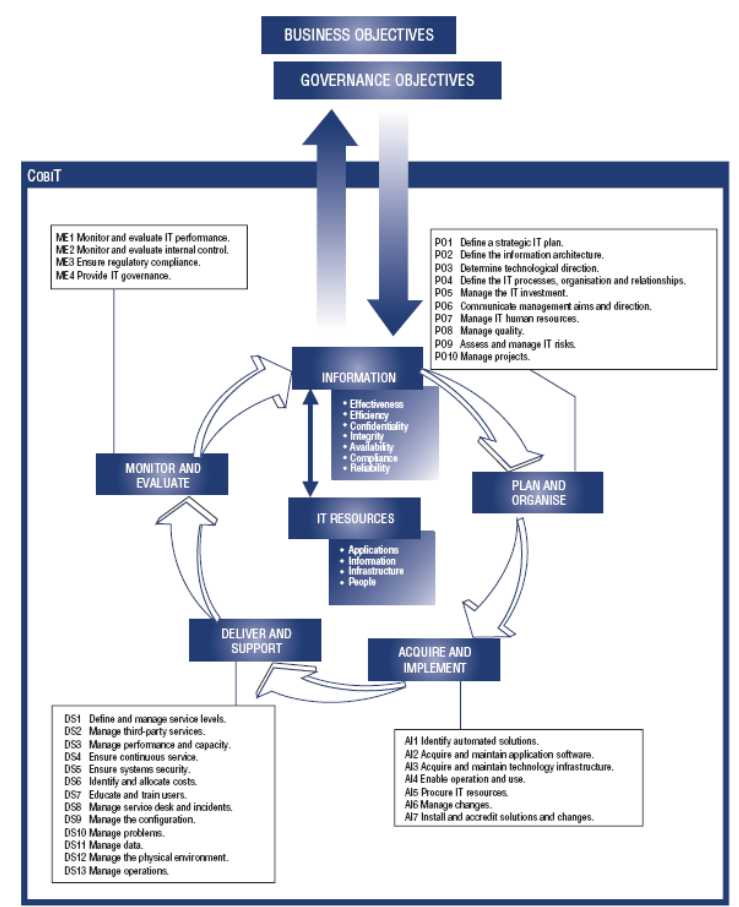

Gambar 2.2. Overall COBIT 4.1 Framework [3]

\section{METODE PENELITIAN}

\section{III.1. Metode Pengumpulan Data [4]:}

\section{A. Data Primer}

1. Wawancara (interview)

Pengumpulan data yang dilakukan dengan cara berkomunikasi langsung dengan pihak terkait. yang dianggap mampu memberikan informasi (auditi).

2. Kuesioner

Kuesioner adalah daftar pertanyaan yang akan digunakan dan disebarkan kepada pihak auditi.

3. Observasi

Pengumpulan data melalui pengamatan dan pencatatan data secara langsung di lapangan terhadap proses yang terjadi.

\section{B. Data Sekunder}

1. Studi Pustaka

Metode pengumpulan data dengan mencari data kepustakaan yang menunjang.

2. Rencana Strategis (RENSTRA) UNIVERSITAS PQR Tahun 2016-2020. [5]

\section{III.2. Waktu dan Tempat Penelitian.}

Pelaksanaan penelitian dilaksanakan pada bulan Maret sampai dengan bulan Agustus 2016 di UNIVERSITAS PQR. 


\section{III.3. Diagram Alir Perancangan Tata Kelola TI UNIVERSITAS PQR}

Alur penelitian yang dilaksanakan dapat dilihat pada Gambar 3.1.

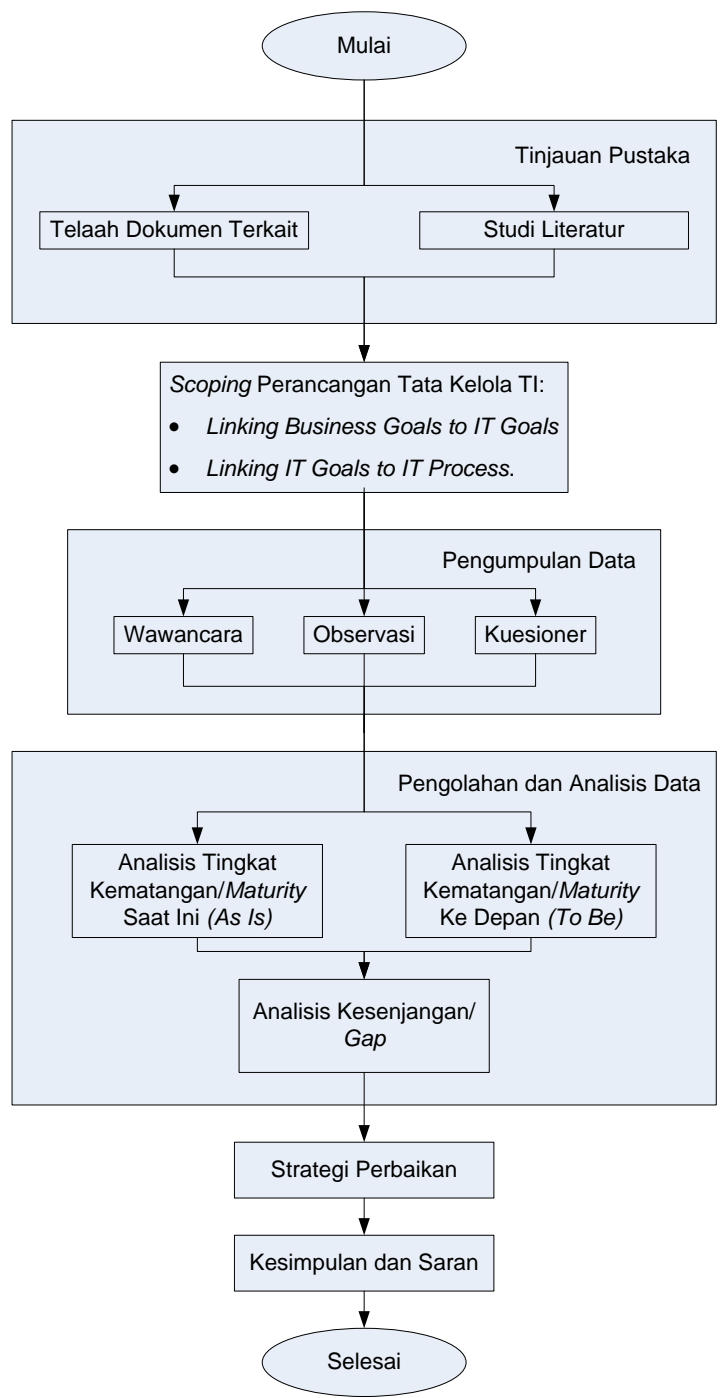

Gambar 3.1. Diagram Alir Penelitian

\section{HASIL DAN PEMBAHASAN}

IV.1. Mengidentifikasi Tujuan Strategis UNIVERSITAS PQR Berdasarkan Pendekatan Metode Balanced Scorecard (BSC)

Pada tahap ini adalah mengidentifikasi tujuan strategi yang disesuaikan dengan visi dan misi UNIVERSITAS PQR dengan menggunakan pendekatan metode Balanced Scorecard (BSC)[6]. 
Guna mendapat bukti identifikasi tujuan strategis tersebut dapat dilihat pada gambar 4.1 berikut :

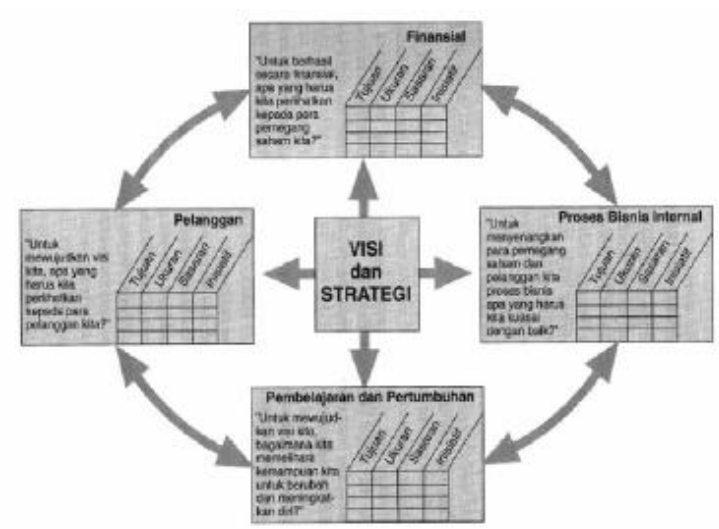

Gambar 4.1. Perspektif Balanced Scorecard [6]

\section{IV.1.1. Hasil Pengukuran Perspektif Tujuan Strategis UNIVERSITAS PQR Berdasarkan Pendekatan Metode Balanced Scorecard (BSC)}

Hasil pengukuran perspektif tujuan strategis UNIVERSITAS PQR menggunakan pendekatan metode BSC dapat dilihat pada tabel 4.1 berikut :

\section{Tabel 4.1. Hasil Pengukuran Perspektif Tujuan Strategis UNIVERSITAS PQR} PENETAPAN SASARAN DAN INISIATIF STRATEGIK

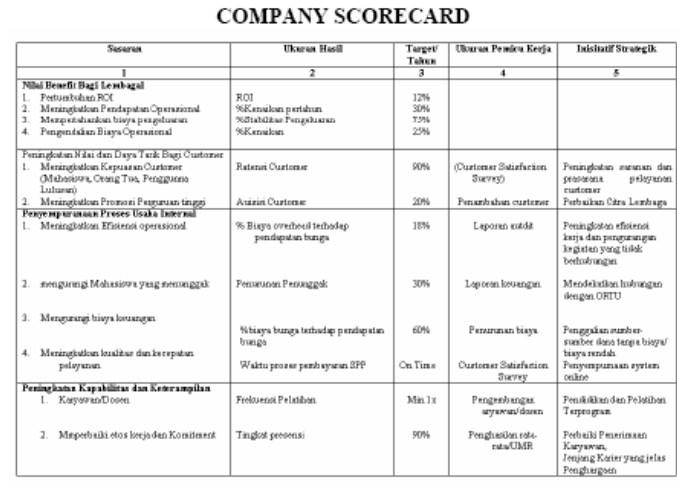

\section{IV.1.2. Penetapan Perspektif Tujuan Strategis UNIVERSITAS PQR}

Pada tahap ini dilakukan penetapan perspektif tujuan strategis UNIVERSITAS PQR hasil pengukuran BSC yang selaras dengan COBIT 4.1 Common Business Goals. Perspektif tersebut terlihat pada Tabel 4.2 berikut ini : 


\section{Tabel 4.2. Perspektif Tujuan Strategis UNIVERSITAS PQR [6]}

\begin{tabular}{|c|ll|}
\hline \multirow{2}{*}{ Perspektif } & \multicolumn{1}{|c|}{ Tujuan Strategis } \\
\hline \multirow{4}{*}{ Keuangan } & 1. & Pertumbuhan ROI \\
\cline { 2 - 3 } & 2. & $\begin{array}{l}\text { Meningkatkan pendapatan } \\
\text { organisasi/institusi }\end{array}$ \\
\cline { 2 - 3 } & 3. & $\begin{array}{l}\text { Mempertahankan biaya } \\
\text { pengeluaran }\end{array}$ \\
\cline { 2 - 3 } Pelanggan & 4. & Pengendalian biaya operasional \\
\hline \multirow{5}{*}{ Proses Internal } & 5. & $\begin{array}{l}\text { Meningkatkan kepuasan } \\
\text { pelanggan (mahasiswa, orang } \\
\text { tua, pengguna lulusan) }\end{array}$ \\
\cline { 2 - 3 } & 6. & $\begin{array}{l}\text { Meningkatkan promosi } \\
\text { perguruan tinggi }\end{array}$ \\
\hline \multirow{5}{*}{ Pembelajaran dan } & 7. & $\begin{array}{l}\text { Meningkatkan efisiensi } \\
\text { operasional }\end{array}$ \\
\cline { 2 - 3 } Pengembangan & 8. & $\begin{array}{l}\text { Mengurangi mahasiswa yang } \\
\text { menunggak }\end{array}$ \\
\cline { 2 - 3 } & 9. & Menekan biaya keuangan \\
\cline { 2 - 3 } & 10. & $\begin{array}{l}\text { Meningkatkan kualitas dan } \\
\text { kecepatan pelayanan }\end{array}$ \\
\cline { 2 - 3 } & 11. & $\begin{array}{l}\text { Meningkatkan kemampuan dan } \\
\text { ketrampilan dosen dan } \\
\text { karyawan }\end{array}$ \\
\hline & 12. & $\begin{array}{l}\text { Memperbaiki etos kerja dan } \\
\text { komitmen }\end{array}$ \\
\hline
\end{tabular}

\section{IV.2. Identifikasi COBIT Common Bussiness Goals}

Pada tahap ini diidentifikasi Bussiness Goal pada COBIT 4.1 yaitu Tables Linking Goals and Process yang terdiri dari tujuh belas business goals. Tabel 4.3. memperlihatkan identifikasi tersebut [7].

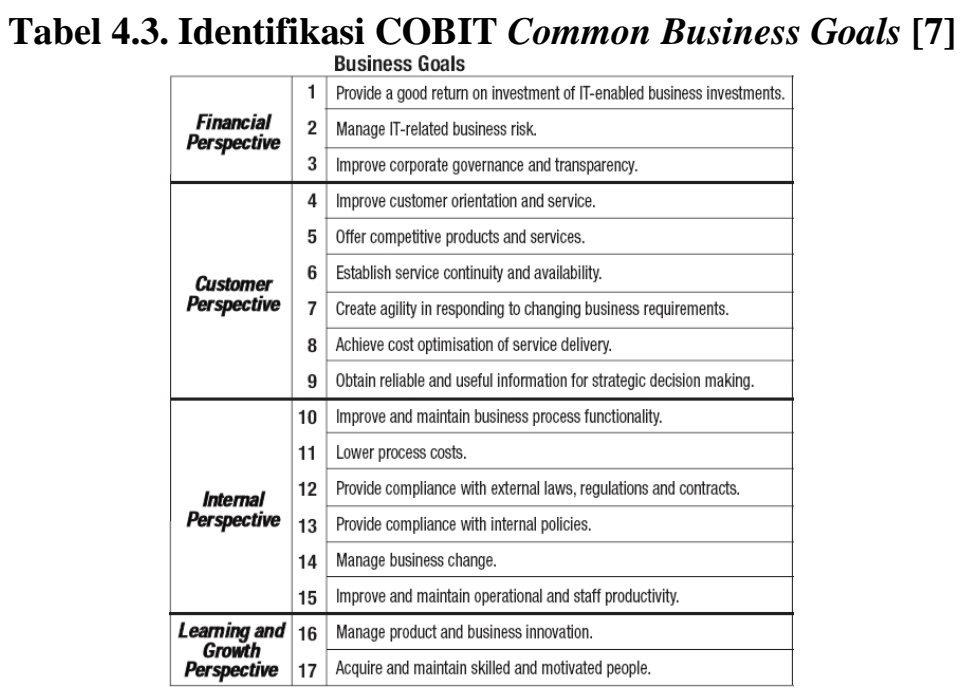

\section{IV.3. Identifikasi COBIT Common IT Goals}

Pada tahap ini diidentifikasi IT Goals (ITG) pada COBIT 4.1 yaitu Tables Linking Goals and Process yang terdiri dari dua puluh delapan IT goals. Tabel 4.4 memperlihatkan identifikasi tersebut [7]. 
Tabel 4.4. Identifikasi COBIT Common IT Goals [7]

\begin{tabular}{|c|c|}
\hline & Respond to business requirements in alignment with the business strategy. \\
\hline & 2 Respond to governance requirements in line with board direction. \\
\hline & 3 Ensure satisfaction of end users with service offerings and service levels. \\
\hline & 4 Optimise the use of information. \\
\hline & 5 Create IT agility. \\
\hline & 6 Define how business functional and control requirements are translated in effective and efficient automated solutions. \\
\hline & Acquire and maintain integrated and standardised application systems. \\
\hline & B Acquire and maintain an integrated and standard dised IT infrastructure. \\
\hline & Acquire and maintain IT skills that respond to the IT strategy. \\
\hline & 0 Ensure mutual satisfaction of third-party relationships. \\
\hline & 1 Ensure seamless integration of applications into business processes. \\
\hline & 2 Ensure transparency and understanding of IT cost, benefits, strategy, policies and service levels. \\
\hline & 3 Ensure proper use and performance of the applications and technology solutions. \\
\hline & 4 Account for and protect all IT assets. \\
\hline & 5 Optimise the IT infrastructure, resources and capabilities. \\
\hline & 6 Reduce solution and service delivery defects and rework. \\
\hline & 7 Protect the achievement of IT objectives. \\
\hline & 8 Establish clarity of business impact of risks to IT objectives and resources. \\
\hline & 9 Ensure that critical and confidential information is withheld from those who should not have access to it. \\
\hline & o Ensure that automated business transactions and information exchanges can be trusted. \\
\hline & if Ensure that II serviess and infrastructure can property resist and recover from fallures due to error, deliberate attack or disaster. \\
\hline & 2 Ensure minimum business impact in the event of an IT service dissruption or change. \\
\hline & 3 Make sure that IT services are avaliable as required. \\
\hline & 4 Improve IT's cost-efficiency and its contribution to business profitiability. \\
\hline & 5 Deliver projects on time and on budget, meeting quality standards. \\
\hline & 6 Maintain the integrity of information and processing infrastructure. \\
\hline & 7 Ensure IT compliance with laws, regulations and contracts. \\
\hline
\end{tabular}

\section{IV.4. Pemetaan Business Goals COBIT 4.1 dengan Perspektif Tujuan Strategis UNIVERSITAS PQR}

Hasil pemetaan business goals yang sesuai dengan standar kerangka kerja COBIT 4.1, kemudian diselaraskan dengan perspektif tujuan strategis UNIVERSITAS PQR. Namun untuk menjaga obyektivitas dalam penelitian ini, maka dilakukan penentuan siapa saja auditi atau responden terkait dengan perancangan tata kelola TI. Auditi atau resoponden tersebut dapat dilihat pada Tabel 4.5, berikut :

Tabel 4.5. Auditi atau Responden

\begin{tabular}{|c|c|l|c|}
\hline No & $\begin{array}{c}\text { Kode Auditi } \\
\text { atau } \\
\text { Responden }\end{array}$ & \multicolumn{1}{|c|}{$\begin{array}{c}\text { Auditi atau } \\
\text { Responden }\end{array}$} & $\begin{array}{c}\text { Jumlah Auditi } \\
\text { atau } \\
\text { Responden }\end{array}$ \\
\hline 1 & R & Rektor & 1 \\
\hline 2 & DP & $\begin{array}{l}\text { Direktur } \\
\text { Pengembangan }\end{array}$ & 1 \\
\hline 3 & BAU & $\begin{array}{l}\text { Biro Administrasi } \\
\text { Umum }\end{array}$ & 1 \\
\hline 4 & DI & Direktur ICT\&M & 1 \\
\hline 5 & KL & $\begin{array}{l}\text { Kabag Labkom } \\
\text { Center }\end{array}$ \\
\hline
\end{tabular}

Sedangkan untuk penilaian / scoring tingkat kepentingan setiap business goal dan perspektif tujuan strategis UNIVERSITAS PQR seperti terlihat pada Tabel 4.6, dibawah ini:

Tabel 4.6. Deskripsi Penilaian/Scoring untuk Tingkat Kepentingan

\begin{tabular}{|c|c|c|}
\hline No & Skala Score & Tingkat Kepentingan \\
\hline 1 & $1-2$ & Tidak Penting \\
\hline 2 & $3-4$ & Sedikit Penting \\
\hline 3 & $5-6$ & Cukup Penting \\
\hline 4 & $7-8$ & Penting \\
\hline 5 & $9-10$ & Sangat Penting \\
\hline
\end{tabular}


Bukti/evidence hasil observasi dan wawancara ke beberapa auditi atau responden yang terkait dengan penentuan score Business Goals terlihat pada Tabel 4.7, yang menunjukkan jawaban penilaian/scoring auditi atau responden terhadap Business Goals

Tabel 4.7. Identifikasi Penilaian/Scoring Business Goals dari Auditi atau Responde

\begin{tabular}{|c|c|c|c|c|c|c|c|c|}
\hline \multirow{2}{*}{ No } & \multirow{2}{*}{$\begin{array}{l}\text { Kode } \\
\text { Bustivess } \\
\text { Goals }\end{array}$} & \multirow{2}{*}{ 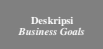 } & \multicolumn{5}{|c|}{ Aduditi a tan Respanden } & \multirow{2}{*}{$\begin{array}{c}\text { Remat } \\
\text { rata }\end{array}$} \\
\hline & & & ${ }_{\mathrm{R}}$ & $\mathrm{DP}$ & $\frac{\mathrm{BAO}}{\mathrm{B}}$ & $\mathrm{DI}$ & $\mathrm{KL}$ & \\
\hline 1 & BG1 & 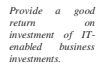 & 10 & 10 & 10 & 10 & 10 & 10 \\
\hline 2 & ${ }_{\mathrm{BG} 2}$ & 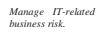 & 6 & 6 & 3 & ${ }^{4}$ & 4 & 4.6 \\
\hline 3 & $\mathrm{BC} 3$ & 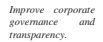 & 1 & 1 & 1 & 1 & 1 & 1 \\
\hline 4 & ${ }_{\mathrm{BG}} 4$ & 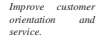 & 10 & 10 & 10 & 10 & 10 & 10 \\
\hline 5 & BGS & 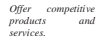 & ${ }_{10}^{10}$ & ${ }_{10}^{10}$ & 10 & 10 & 10 & 10 \\
\hline$\circ$ & $\mathrm{BG} 6$ & 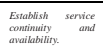 & 7 & 7 & 4 & 4 & 4 & 5,2 \\
\hline 7 & BG7 & 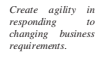 & I & $\mathrm{I}$ & 1 & 1 & 1 & 1 \\
\hline 8 & BGs & 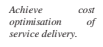 & ${ }_{10}^{10}$ & 10 & 8 & 9 & 9 & 9,2 \\
\hline 9 & BG9 & 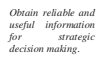 & 6 & 6 & 5 & 3 & 3 & 4.6 \\
\hline 10 & BG10 & 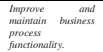 & 6 & 6 & 5 & 5 & 5 & 5,4 \\
\hline 11 & BGI1 & $\begin{array}{l}\text { Lower } \\
\text { cosps. }\end{array}$ & 10 & 10 & 10 & 10 & 10 & ${ }_{10}$ \\
\hline 12 & BG12 & 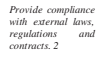 & 6 & 6 & 3 & 3 & 3 & 4,2 \\
\hline 13 & BG13 & 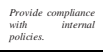 & 10 & 10 & 8 & 8 & 8 & 8.8 \\
\hline${ }^{14}$ & BGI4 & $\begin{array}{l}\text { Mangage } \\
\text { changsiness } \\
\text { chang }\end{array}$ & 1 & 1 & 1 & 1 & 1 & 1 \\
\hline 15 & BG15 & 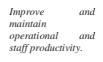 & 10 & ${ }_{10}^{10}$ & 10 & 10 & ${ }_{10}^{10}$ & ${ }_{10}^{10}(x)$ \\
\hline 16 & BG16 & 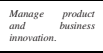 & 5 & 5 & 4 & 1 & 1 & 3,2 \\
\hline 17 & BG17 & 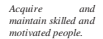 & ${ }_{10}^{10}$ & ${ }_{10}^{10}$ & 10 & 10 & 10 & 10 \\
\hline
\end{tabular}

\section{IV.5. Identifikasi Business Goals COBIT 4.1 Terpilih}

Dari proses pemetaan tujuan strategis UNIVERSITAS PQR dengan Business Goals COBIT 4.1., maka dapat diidentifikasi empat belas (14) business goals terpilih seperti terlihat pada Tabel 4.8 , berikut:

Tabel 4.8. Identifikasi Business Goals COBIT 4.1 Terpilih [7]

\begin{tabular}{|c|c|l|}
\hline Nol & $\begin{array}{c}\text { Kode } \\
\text { Business } \\
\text { Goals }\end{array}$ & \multicolumn{1}{c|}{$\begin{array}{c}\text { Deskripsi } \\
\text { Business Goals }\end{array}$} \\
\hline 1 & BG1 & $\begin{array}{l}\text { Provide a good return on investment of IT-enabled } \\
\text { business investments. }\end{array}$ \\
\hline 2 & BG2 & Manage IT-related business risk. \\
\hline 3 & BG4 & Improve customer orientation and service. \\
\hline 4 & BG5 & Offer competitive products and services. \\
\hline 5 & BG6 & Establish service continuity and availability. \\
\hline 6 & BG8 & Achieve cost optimisation of service delivery. \\
\hline 7 & BG9 & $\begin{array}{l}\text { Obtain reliable and useful information for strategic } \\
\text { decision making. }\end{array}$ \\
\hline 8 & BG10 & Improve and maintain business process functionality. \\
\hline 9 & BG11 & Lower process costs. \\
\hline
\end{tabular}




\begin{tabular}{|c|c|l|}
\hline 10 & BG12 & $\begin{array}{l}\text { Provide compliance with external laws, regulations } \\
\text { and contracts. }\end{array}$ \\
\hline 11 & BG13 & Provide compliance with internal policies. \\
\hline 12 & BG15 & $\begin{array}{l}\text { Improve and maintain operational and staff } \\
\text { productivity. }\end{array}$ \\
\hline 13 & BG16 & Manage product and business innovation. \\
\hline 14 & BG17 & Acquire and maintain skilled and motivated people. \\
\hline
\end{tabular}

\section{IV.6. Pemetaan dan Identifikasi IT Goals Berdasarkan Business Goals Terpilih}

Dari business goals yang sudah teridentifikasi sebelumnya, maka dapat dilakukan pemetaan ke IT goals berdasarkan standar COBIT 4.1 yang dapat dilihat pada Tabel 4.9, sebagai berikut:

Tabel 4.9. Pemetaan IT Goals Berdasarkan Business Goals Terpilih [7]

\begin{tabular}{|c|c|l|}
\hline No & $\begin{array}{c}\text { Kode } \\
\text { Business Goals }\end{array}$ & \multicolumn{1}{c|}{$\begin{array}{c}\text { Kode } \\
\text { IT Goals }\end{array}$} \\
\hline 1 & BG1 & ITG24 \\
\hline 2 & BG2 & ITG2, ITG14, ITG17, ITG18, ITG19, ITG20, ITG21, ITG22 \\
\hline 3 & BG4 & ITG3, ITG23 \\
\hline 4 & BG5 & ITG5, ITG24 \\
\hline 5 & BG6 & ITG10, ITG16, ITG22, ITG23 \\
\hline 6 & BG8 & ITG7, ITG8, ITG10, ITG24 \\
\hline 7 & BG9 & ITG2, ITG4, ITG12, ITG20, ITG26 \\
\hline 8 & BG10 & ITG6, ITG7, ITG11 \\
\hline 9 & BG11 & ITG7, ITG8, ITG13, ITG15, ITG24 \\
\hline 10 & BG12 & ITG2, ITG19, ITG20, ITG21, ITG22, ITG26, ITG27 \\
\hline 11 & BG13 & ITG2, ITG13 \\
\hline 12 & BG15 & ITG7, ITG8, ITG11, ITG13 \\
\hline 13 & BG16 & ITG5, ITG25, ITG28 \\
\hline 14 & BG17 & ITG9 \\
\hline
\end{tabular}

Dari pemetaan IT goals berdasarkan business goals diatas, maka dapat diidentifikasi IT goals terpilih sesuai dengan COBIT 4.1, hal tersebut dapat dilihat pada Tabel 4.10, di bawah ini:

Tabel 4.10. Identifikasi IT Goals Berdasarkan Business Goals Terpilih [7]

\begin{tabular}{|c|c|l|}
\hline No & $\begin{array}{c}\text { Kode } \\
\text { IT Goals }\end{array}$ & \multicolumn{1}{c|}{$\begin{array}{c}\text { Deskripsi } \\
\text { IT Goals }\end{array}$} \\
\hline 1 & ITG2 & Respond to governance requirements in line with board direction. \\
\hline 2 & ITG3 & Ensure satisfaction of end users with service offerings and service levels. \\
\hline 3 & ITG4 & Optimise the use of information. \\
\hline 4 & ITG5 & Create IT agility. \\
\hline 5 & ITG6 & $\begin{array}{l}\text { Define how business functional and control requirements are translated in } \\
\text { effective and efficient automated solutions. }\end{array}$ \\
\hline 6 & ITG7 & Acquire and maintain integrated and standardised application systems. \\
\hline 7 & ITG8 & Acquire and maintain an integrated and standardised IT infrastructure. \\
\hline 8 & ITG9 & Acquire and maintain IT skills that respond to the IT strategy. \\
\hline 9 & ITG10 & Ensure mutual satisfaction of third-party relationships. \\
\hline 10 & ITG11 & Ensure seamless integ ration of applications into business processes. \\
\hline
\end{tabular}




\begin{tabular}{|c|c|c|}
\hline 11 & ITG12 & $\begin{array}{l}\text { Ensure transparency and understanding of IT cost, benefits, strategy, policies } \\
\text { and service levels. }\end{array}$ \\
\hline 12 & ITG13 & $\begin{array}{l}\text { Ensure proper use and performance of the applications and technology } \\
\text { solutions. }\end{array}$ \\
\hline 13 & ITG14 & Account for and protect all IT assets. \\
\hline 14 & ITG15 & Optimise the IT infrastructure, resources and capabilities. \\
\hline 15 & ITG16 & Reduce solution and service delivery defects and rework. \\
\hline 16 & ITG17 & $\begin{array}{l}\text { Protect the achievement of IT objectives. } \\
\text {. }\end{array}$ \\
\hline 17 & ITG18 & Establish clarity of business impact of risks to IT objectives and resources. \\
\hline 18 & ITG19 & $\begin{array}{l}\text { Ensure that critical and confidential information is withheld from those who } \\
\text { should not have access to it. }\end{array}$ \\
\hline 19 & ITG20 & $\begin{array}{l}\text { Ensure that automated business transactions and information exchanges can } \\
\text { be trusted. }\end{array}$ \\
\hline 20 & ITG21 & $\begin{array}{l}\text { Ensure that IT services and infrastructure can properly resist and recover } \\
\text { from failures due to error, deliberate attack or disaster. }\end{array}$ \\
\hline 21 & ITG22 & $\begin{array}{l}\text { Ensure minimum business impact in the event of an IT service disruption or } \\
\text { change. }\end{array}$ \\
\hline 22 & ITG23 & Make sure that IT services are available as require. \\
\hline 23 & ITG24 & Improve IT's cost-efficiency and its contribution to business profitability. \\
\hline 24 & ITG25 & Deliver projects on time and on budget, meeting quality standards. \\
\hline 25 & ITG26 & Maintain the integrity of information and processing infrastructure \\
\hline 26 & ITG27 & $\begin{array}{l}\text { Ensure IT compliance with laws, regulations and contracts. } \\
\text {. }\end{array}$ \\
\hline 27 & ITG28 & $\begin{array}{l}\text { Ensure that IT demonstrates cost-efficient service quality, continuous. } \\
\text { improvement and readiness for future change. }\end{array}$ \\
\hline
\end{tabular}

\section{IV.7. Pemetaan dan Identifikasi IT Process Berdasarkan IT Goals Terpilih}

Dari IT goals yang sudah teridentifikasi sebelumnya, maka dapat dilakukan pemetaan ke IT process berdasarkan standar COBIT 4.1 yang dapat dilihat pada Tabel 4.11, sebagai berikut:

Tabel 4.11. Pemetaan IT Process Berdasarkan IT Goals Terpilih [7]

\begin{tabular}{|c|c|l|}
\hline $\begin{array}{c}\text { Kode } \\
\text { IT Goals }\end{array}$ & \multicolumn{1}{c|}{$\begin{array}{c}\text { Kode } \\
\text { IT Process }\end{array}$} \\
\hline 1 & ITG2 & PO1, PO4, PO10, ME1, ME4 \\
\hline 2 & ITG3 & PO8, AI4, DS1, DS2, DS7, DS8, DS10, DS13 \\
\hline 3 & ITG4 & PO2, DS11 \\
\hline 4 & ITG5 & PO2, PO4, PO7, AI3 \\
\hline 5 & ITG6 & AI1, AI2, AI6 \\
\hline 6 & ITG7 & PO3, AI2, AI5 \\
\hline 7 & ITG8 & AI3, AI5 \\
\hline 8 & ITG9 & PO7, AI5 \\
\hline 9 & ITG10 & DS2 \\
\hline 10 & ITG11 & PO2, AI4, AI7 \\
\hline 11 & ITG12 & PO5, PO6, DS1, DS2, DS6, ME1, ME4 \\
\hline 12 & ITG13 & PO6, AI4, AI7, DS7, DS8 \\
\hline 13 & ITG14 & PO9, DS5, DS9, DS12, ME2 \\
\hline 14 & ITG15 & PO3, AI3, DS3, DS7, DS9 \\
\hline 15 & ITG16 & PO8, AI4, AI6, AI7, DS10 \\
\hline 16 & ITG17 & PO9, DS10, ME2 \\
\hline 17 & ITG18 & PO9 \\
\hline 18 & ITG19 & PO6, DS5, DS11, DS12 \\
\hline 19 & ITG20 & PO6, AI7, DS5 \\
\hline 20 & ITG21 & PO6, AI7, DS4, DS5, DS12, DS13, ME2 \\
\hline 21 & ITG22 & PO6, AI6, DS4, DS12 \\
\hline 22 & ITG23 & DS3, DS4, DS8, DS13 \\
\hline & & \\
\hline 12 & \\
\hline 10
\end{tabular}




\begin{tabular}{|c|c|l|}
\hline 23 & ITG24 & PO5, DS6 \\
\hline 24 & ITG25 & PO8, PO10 \\
\hline 25 & ITG26 & AI6, DS5 \\
\hline 26 & ITG27 & DS11, ME2, ME3, ME4 \\
\hline 27 & ITG28 & PO5, DS6, ME1, ME4 \\
\hline
\end{tabular}

Dari pemetaan IT process berdasarkan IT goals diatas, maka dapat diidentifikasi IT process terpilih sesuai dengan COBIT 4.1, hal tersebut dapat dilihat pada Tabel 4.12, di bawah ini:

Tabel 4.12. Identifikasi IT Process Berdasarkan IT Goals Terpilih [7]

\begin{tabular}{|c|c|c|}
\hline No & $\begin{array}{c}\text { Kode } \\
\text { IT Process }\end{array}$ & $\begin{array}{l}\text { Deskripsi } \\
\text { IT Process }\end{array}$ \\
\hline 1 & PO1 & Define a strategic IT plan \\
\hline 2 & $\mathrm{PO} 2$ & Define the information architecture \\
\hline 3 & PO3 & Determine technological direction \\
\hline 4 & PO4 & Define the IT processes, organisation and relationships \\
\hline 5 & PO5 & Manage the IT investment \\
\hline 6 & PO6 & Communicate management aims and direction \\
\hline 7 & $\mathrm{PO} 7$ & Manage IT human resources \\
\hline 8 & PO8 & Manage quality \\
\hline 9 & $\mathrm{PO} 9$ & Assess and manage IT risks. \\
\hline 10 & PO10 & Manage projects \\
\hline 11 & AI1 & Identify automated solutions. \\
\hline 12 & $\mathrm{AI} 2$ & Acquire and maintain application software \\
\hline 13 & $\mathrm{AI} 3$ & Acquire and maintain technology infrastructure. \\
\hline 14 & AI4 & Enable operation and use \\
\hline 15 & AI5 & Procure IT resources \\
\hline 16 & AI6 & Manage changes. \\
\hline 17 & $\mathrm{AI} 7$ & Install and accredit solutions and changes \\
\hline 18 & DS1 & Define and manage service levels \\
\hline 19 & DS2 & Manage third-party services \\
\hline 20 & DS3 & Manage performance and capacity \\
\hline 21 & DS4 & Ensure continuous service \\
\hline 22 & DS5 & Ensure systems security. \\
\hline 23 & DS6 & Identify and allocate costs \\
\hline 24 & DS7 & Educate and train users. \\
\hline 25 & DS8 & Manage service desk and incidents \\
\hline 26 & DS9 & Manage the configuration. \\
\hline 27 & DS10 & Manage problems \\
\hline 28 & DS11 & Manage data. \\
\hline 29 & DS12 & Manage the physical environment. \\
\hline 30 & DS13 & Manage operations \\
\hline 31 & ME1 & Monitor and evaluate IT performance \\
\hline 32 & ME2 & Monitor and evaluate internal control. \\
\hline 33 & ME3 & Ensure compliance with external requirements. \\
\hline 34 & ME4 & Provide IT governance \\
\hline
\end{tabular}

\section{IV.8. Penentuan Tingkat Kematangan Proses TI}

Untuk menentukan tingkat kematangan dilakukan dengan cara memetakan perspektif tujuan strategis UNIVERSITAS PQR dengan business goals COBIT 4.1 yang terpilih dengan tujuan memberikan penilaian kondisi tata kelola TI existing. yang didapatkan melalui proses wawancara dan penyebaran kuesioner kepada auditi atau responden yang terkait dengan tujuan penelitian. 


\section{IV.8.1. Scoring Business Goals Menggunakan COBIT 4.1-Maturity Assessment Tool}

Pada tahap ini terdapat proses yang harus dilakukan, yaitu memberikan score untuk setiap perspektif tujuan strategis yang diterjemahakan kedalam business goals COBIT 4.1 berdasarkan Rencana Strategis (RENSTRA) tahun 2016-2020. Proses pemberian score untuk business goals dapat dilihat seperti pada Tabel 4.13, di bawah ini:

Tabel 4.13. Penilaian/Scoring Business Goals [7]

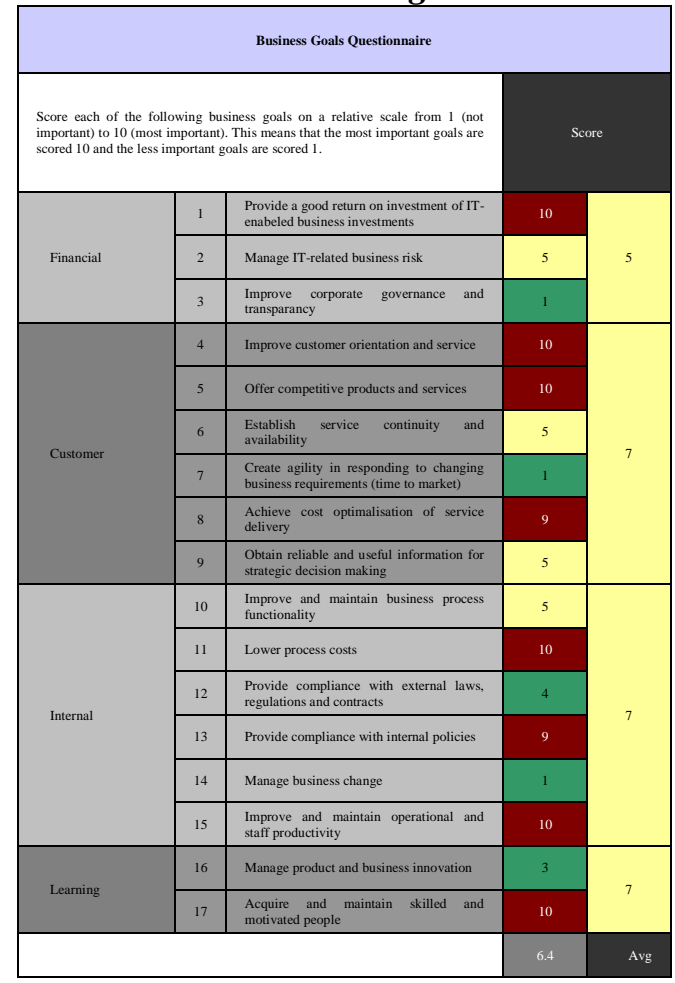

\section{IV.8.2. Score IT Goals Berangkat dari Scoring Business Goals}

Pada tahap ini mengidentifikasi score IT goals berdasarkan score yang telah ditetapkan pada business goals sebelumnya. Score IT goals ini secara otomatis akan digenarate oleh COBIT 4.1-Maturity Assessment Tool. Scoring IT goals dapat dilihat pada Tabel 4.14 berikut ini:

Tabel 4.14. Score IT Goals dari Penetapan Scoring Business Goals [7]

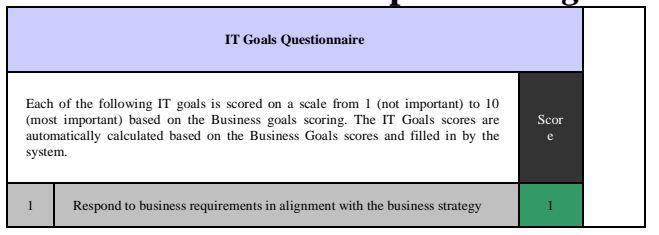




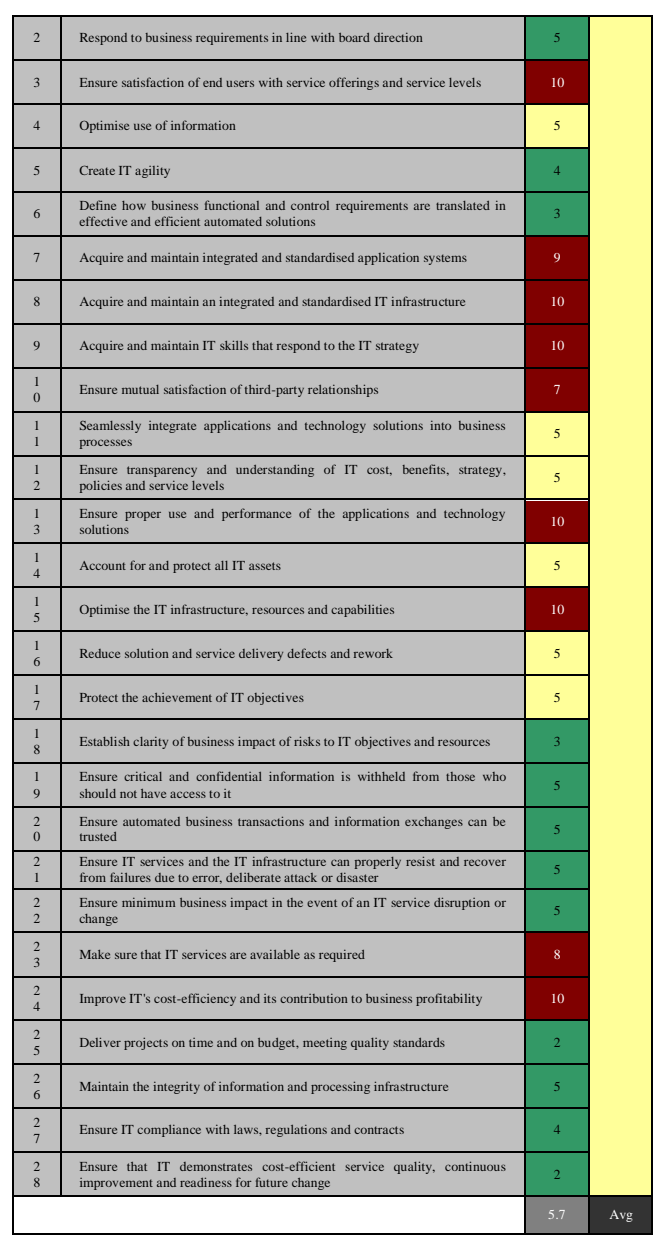

\section{IV.8.3. Hubungan Ruang Lingkup Penilaian Proses TI Terpilih dan Target Tingkat Kematangan}

Pada tahap ini menjelaskan keterhubungan antara proses TI berserta score per domain dan per proses serta persetujuan penilaian yang dipilihkan COBIT 4.1-Maturity Assessment Tool secara otomatis. Keterhubungan tersebut secara detail dapat dilihat pada Tabel 4.15, berikut ini:

Tabel 4.15. Hubungan Antara Proses TI Terpilih, Target Kematangan Kedepan dan Ruang Lingkup Penilaian [7]

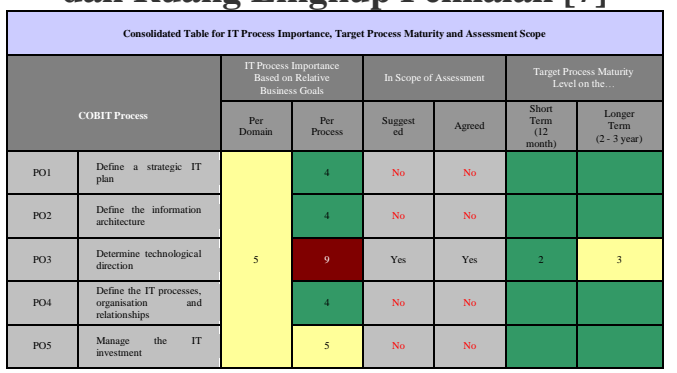




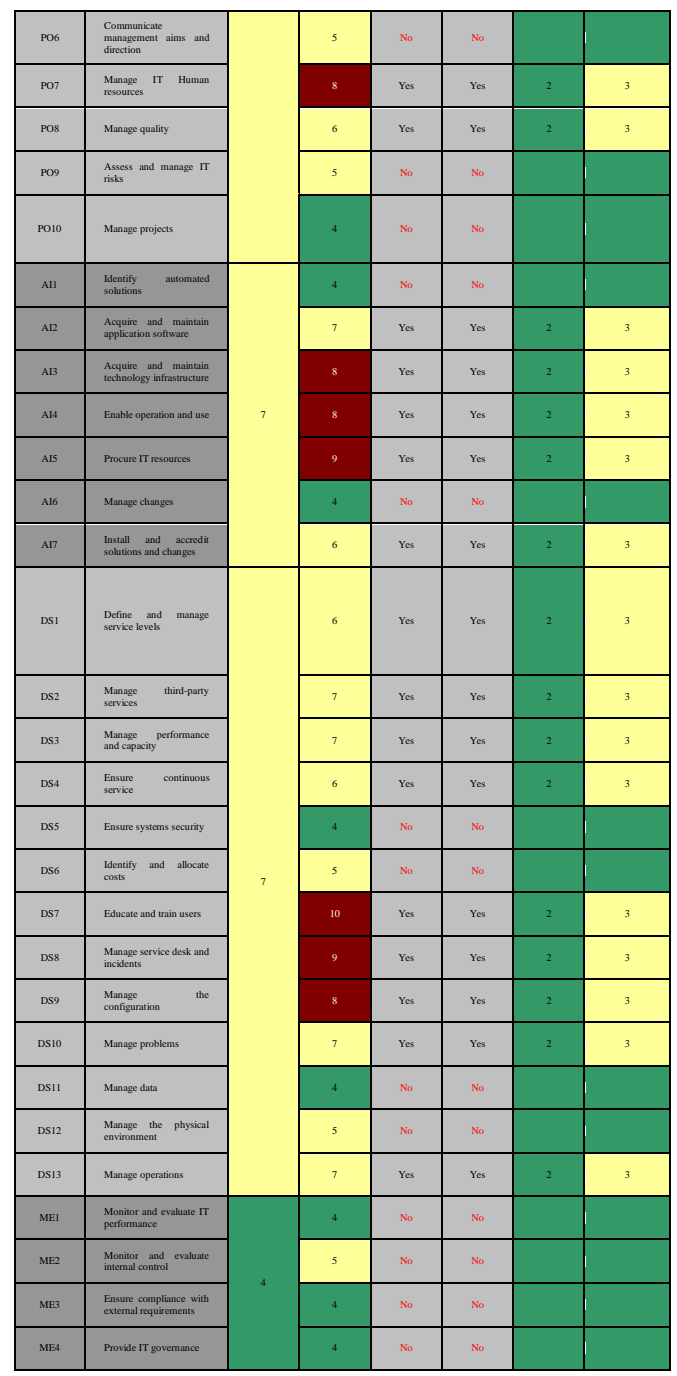

IV.8.4. Proses-proses TI Terpilih Melalui COBIT 4.1-Maturity Assessment Tool

Pada tahap ini akan didapatkan informasi berkaitan dengan proses TI pada COBIT 4.1 yang telah di assessment, meliputi proses TI terpilih, persetujuan COBIT 4.1Maturity Assessment Tools, dan target tingkat kematangan jangka pendek serta jangka panjang, sehingga memudahkan dalam proses selanjutnya yaitu untuk mengetahui tingkat kematangan kondisi existing tata kelola TI UNIVERSITAS PQR. Proses TI yang telah disetujui terlihat pada Tabel 4.16, dan untuk diagram target tingkat kematangan baik jangka pendek maupun jangka panjang dapat dilihat pada Gambar 4.2.

Tabel 4.16. Proses TI Terpilih yang Disetujui [7]

\begin{tabular}{|c|c|c|c|c|c|}
\hline \multicolumn{2}{|c|}{ COBIT IT Processes } & Suggested & Agreed & $\begin{array}{c}\text { Short } \\
\text { Term }\end{array}$ & $\begin{array}{c}\text { Longer } \\
\text { Termm }\end{array}$ \\
\hline P03 & $\begin{array}{l}\text { Determine technological } \\
\text { dirirccion }\end{array}$ & Yes & Yes & 2 & 3 \\
\hline P07 & $\begin{array}{l}\text { Manage IT Human } \\
\text { resources }\end{array}$ & Yes & Yes & 2 & 3 \\
\hline P08 & Manage quality & Yes & Yes & 2 & 3 \\
\hline A12 & $\begin{array}{l}\text { Acquire and maintain } \\
\text { application software }\end{array}$ & Yes & Yes & 2 & 3 \\
\hline A13 & $\begin{array}{l}\text { Acquire and maintain } \\
\text { technology ynfrastructure }\end{array}$ & Yes & Yes & 2 & 3 \\
\hline
\end{tabular}




\begin{tabular}{|c|l|c|c|c|c|}
\hline AI4 & Enable operation and use & Yes & Yes & 2 & 3 \\
\hline AI5 & Procure IT resources & Yes & Yes & 2 & 3 \\
\hline Al7 & $\begin{array}{l}\text { Install and accredit } \\
\text { solutions and changes }\end{array}$ & Yes & Yes & 2 & 3 \\
\hline DS1 & $\begin{array}{l}\text { Define and manage } \\
\text { service levels }\end{array}$ & Yes & Yes & 2 & 3 \\
\hline DS2 & $\begin{array}{l}\text { Manage third-party } \\
\text { services }\end{array}$ & Yes & Yes & 2 & 3 \\
\hline DS3 & $\begin{array}{l}\text { Manage performance and } \\
\text { capacity }\end{array}$ & Yes & Yes & 2 & 3 \\
\hline DS4 & Ensure continuous service & Yes & Yes & 2 & 3 \\
\hline DS7 & Educate and train users & Yes & Yes & 2 & 3 \\
\hline DS8 & $\begin{array}{l}\text { Manage service desk and } \\
\text { incidents }\end{array}$ & Yes & Yes & 2 & 3 \\
\hline DS9 & Manage the configuration & Yes & Yes & 2 & 3 \\
\hline DS10 & Manage problems & Yes & Yes & 2 & 3 \\
\hline DS13 & Manage operations & Yes & Yes & 2 & 3 \\
\hline
\end{tabular}

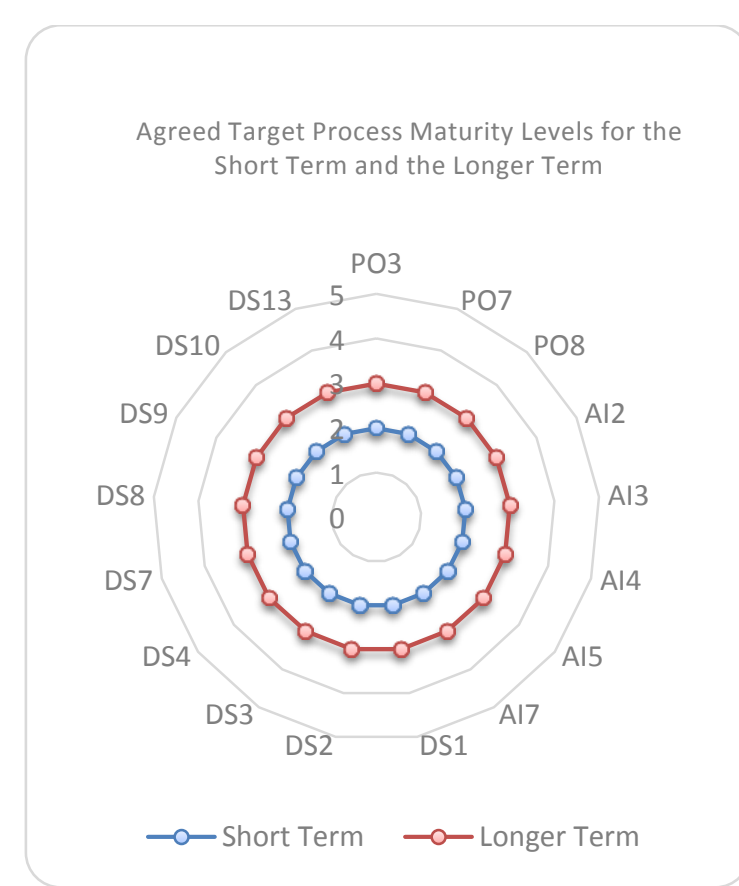

\section{Gambar 4.2. Target Tingkat Kematangan Proses TI Terpilih [7]}

\section{IV.9. Review Hasil Penilaian}

\section{IV.9.1. Perhitungan Tingkat Kematangan Proses-proses TI Terpilih}

Perhitungan tingkat kematangan proses-proses TI terpilih dilakukan secara bertahap untuk setiap proses TI. Perhitungan tersebut dilakukan dengan menggunakan COBIT 4.1-Maturity Assessment Tools dimana untuk setiap proses TI terpilih yang akan dihitung tingkat kematangannya telah disediakan daftar pernyataan atau pertanyaannya berupa worksheet yang berisi langkah / tahap detail dari proses TI terpilih. Auditi atau responden langsung memberikan score penilaian dan persetujuan sesuai dengan score dan skala yang ada untuk setiap pernyataan yang disediakan sesuai dengan kondisi existing tata kelola TI UNIVERSITAS PQR. Setiap pernyataan atau pertanyaan 
memiliki bobot masing-masing dan nilainya dihitung dan ditentukan oleh COBIT 4.1Maturity Assessment Tool. Untuk bobot masing-masing tingkat kematangan ditunjukkan pada Tabel 4.17.

Tabel 4.17. Bobot Tingkat Kematangan Setiap Proses [7]

\begin{tabular}{|c|c|l|}
\hline No & $\begin{array}{c}\text { Nilai Kematangan / Maturity } \\
\text { Atribut }\end{array}$ & \multicolumn{1}{|c|}{ Deskripsi Kematangan / Maturity Atribut } \\
\hline 1 & $0-0,50$ & Non-Existent \\
\hline 2 & $0,51-1,50$ & Initial/Ad Hoc \\
\hline 3 & $1,51-2,50$ & Repeatable but Intuitive \\
\hline 4 & $2,51-3,50$ & Defined Process \\
\hline 5 & $3,51-4,50$ & Managed and Measurable \\
\hline 6 & $4,51-5,00$ & Optimised \\
\hline
\end{tabular}

Hasil perhitungan tingkat kematangan/maturity untuk setiap proses TI yang terpilih pada kondisi existing (as is) tata kelola TI UNIVERSITAS PQR dapat dilihat pada Tabel 4.18, berikut ini:

Tabel 4.18. Nilai Tingkat Kematangan Proses TI Terpilih [7]

\begin{tabular}{|c|c|c|c|c|c|}
\hline No & $\begin{array}{c}I T \\
\text { Proces } \\
s\end{array}$ & $\begin{array}{l}\text { Deskripsi } \\
\text { IT Process }\end{array}$ & $\begin{array}{c}\text { Nilai } \\
\text { Kematanga } \\
\text { n/Maturity } \\
\text { Kondisi } \\
\text { Exisiting } \\
\text { (as is) }\end{array}$ & $\begin{array}{l}\text { Tingkat } \\
\text { Kematan } \\
\text { gan } \\
\text { IMaturity } \\
\text { Kondisi } \\
\text { Existing } \\
\text { (as is) }\end{array}$ & $\begin{array}{c}\text { Keterangan } \\
\text { Tingkat } \\
\text { Kematanga } \\
\text { n Maturity }\end{array}$ \\
\hline 1 & $\mathrm{PO} 3$ & $\begin{array}{l}\text { Determine technological } \\
\text { direction }\end{array}$ & 1.385 & 1 & $\begin{array}{c}\text { Initial/Ad } \\
\text { Hoc }\end{array}$ \\
\hline 2 & PO7 & $\begin{array}{l}\begin{array}{l}\text { Manage } \\
\text { resources }\end{array} \\
\text { IT Human }\end{array}$ & 1.083686 & 1 & $\begin{array}{c}\text { Initial/Ad } \\
\text { Hoc }\end{array}$ \\
\hline 3 & PO8 & Manage quality & 1.33 & 1 & $\begin{array}{l}\text { Initial/Ad } \\
\text { Hoc }\end{array}$ \\
\hline 4 & Al2 & $\begin{array}{l}\text { Acquire and maintain } \\
\text { application soffware }\end{array}$ & 1.962367 & 2 & $\begin{array}{c}\begin{array}{c}\text { Repeatable } \\
\text { But Intuitive }\end{array} \\
\end{array}$ \\
\hline 5 & $\mathrm{Al} 3$ & $\begin{array}{l}\text { Acquire and maintain } \\
\text { technology } \\
\text { infrastructure }\end{array}$ & 1.8514 & 2 & $\begin{array}{l}\text { Repeatable } \\
\text { But Intuitive }\end{array}$ \\
\hline 6 & $\mathrm{~A} 14$ & $\begin{array}{l}\begin{array}{l}\text { Enable operation and } \\
\text { use }\end{array} \\
\text { a }\end{array}$ & 1.279451 & 1 & $\begin{array}{c}\text { Initial/Ad } \\
\text { Hoc }\end{array}$ \\
\hline 7 & Al5 & Procure IT resources & 0.8811 & 1 & $\begin{array}{c}\text { Initial/Ad } \\
\text { Hoc }\end{array}$ \\
\hline 8 & Al7 & $\begin{array}{l}\text { Install and accredit } \\
\text { solutions and changes }\end{array}$ & 1.490286 & 1 & $\begin{array}{c}\text { Initial/Ad } \\
\text { Hoc }\end{array}$ \\
\hline 9 & DS1 & $\begin{array}{l}\begin{array}{l}\text { Define and manage } \\
\text { service levels }\end{array} \\
\end{array}$ & 1.66 & 2 & $\begin{array}{c}\begin{array}{c}\text { Repeatable } \\
\text { But Intuitive }\end{array} \\
\text { But }\end{array}$ \\
\hline 10 & DS2 & $\begin{array}{l}\begin{array}{l}\text { Manage } \\
\text { services }\end{array} \\
\text { third-party } \\
\end{array}$ & 0.5511 & 1 & $\begin{array}{c}\text { Initial/Ad } \\
\text { Hoc }\end{array}$ \\
\hline 11 & DS3 & $\begin{array}{l}\text { Manage performance } \\
\text { and capacity }\end{array}$ & 1.281758 & 1 & $\begin{array}{c}\text { Initial/Ad } \\
\text { Hoc }\end{array}$ \\
\hline 12 & DS4 & $\begin{array}{l}\begin{array}{l}\text { Ensure } \\
\text { service }\end{array} \\
\text { continuous } \\
\end{array}$ & 1.341239 & 1 & $\begin{array}{c}\text { Initial/Ad } \\
\text { Hoc }\end{array}$ \\
\hline 13 & DS7 & Educate and train users & 1.46753 & 1 & $\begin{array}{l}\text { Initial/Ad } \\
\text { Hoc }\end{array}$ \\
\hline 14 & DS8 & $\begin{array}{l}\begin{array}{l}\text { Manage service desk } \\
\text { and incidents }\end{array} \\
\end{array}$ & 1.203797 & 1 & $\begin{array}{c}\text { Initial/Ad } \\
\text { Hoc }\end{array}$ \\
\hline 15 & DS9 & $\begin{array}{l}\begin{array}{l}\text { Manage } \\
\text { configuration }\end{array} \\
\text { che }\end{array}$ & 1.462 & 1 & $\begin{array}{l}\text { Initial/Ad } \\
\text { Hoc }\end{array}$ \\
\hline 16 & DS10 & Manage problems & 1.383036 & 1 & $\begin{array}{c}\text { Initial/Ad } \\
\text { Hoc }\end{array}$ \\
\hline 17 & DS13 & Manage operations & 1.644284 & 2 & $\begin{array}{l}\text { Repeatable } \\
\text { But Intuitive }\end{array}$ \\
\hline
\end{tabular}

Hasil penilaian tingkat kematangan proses TI terpilih dengan nilai kondisi existing dapat ditunjukkan pada Gambar 4.3, berikut : 


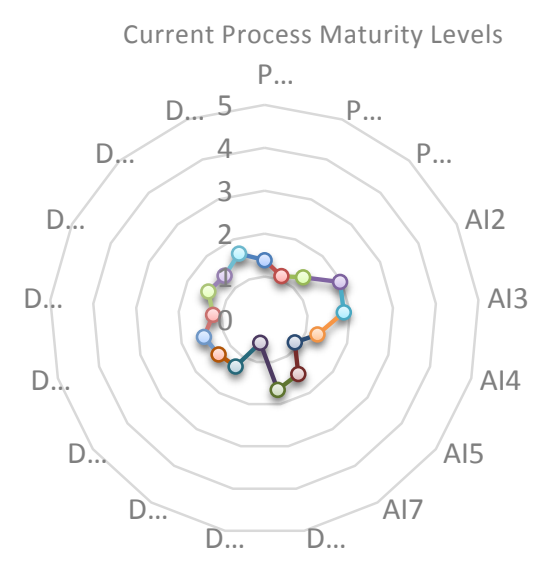

Gambar 4.3. Diagram Proses TI Terpilih pada Kondisi Existing [7]

\section{IV.9.2. Analisis Kesenjangan Tingkat Kematangan Proses-proses TI Terpilih}

Dengan melihat kondisi tingkat kematangan proses TI terpilih yang ada di UNIVERSITAS PQR saat ini dibandingkan dengan kondisi ideal tingkat kematangan proses TI yang diinginkan, maka akan memunculkan suatu penyesuaian dengan kondisi normatif berdasarkan kerangka kerja (framework). Penyesuaian dilakukan untuk menutup kesenjangan yang disebabkan dari tingkat kematangan proses saat ini (Current Maturity Level) dengan kondisi ideal tingkat kematangan/maturity proses yang diinginkan (Target Maturity Level). Tabel 4.19 menunjukkan adanya kesenjangan/gap pada tujuh belas (17) proses TI terpilih di UNIVERSITAS PQR.

Tabel 4.19. Kesenjangan/Gap Tingkat Kematangan Kondisi Existing dengan Target Kondisi Ke Depan [7]

\begin{tabular}{|c|c|c|c|c|c|c|c|}
\hline \multirow{3}{*}{ No } & \multirow{3}{*}{$\begin{array}{c}I T \\
\text { Process }\end{array}$} & \multirow{3}{*}{$\begin{array}{l}\text { Deskripsi } \\
\text { IT Process }\end{array}$} & \multicolumn{5}{|c|}{ Penilaian Tingkat Kematangan/Maturity } \\
\hline & & & \multicolumn{2}{|c|}{ Target } & \multirow{2}{*}{$\begin{array}{c}C u \\
r r e \\
n t\end{array}$} & \multicolumn{2}{|c|}{ Gap } \\
\hline & & & Short-Term & $\begin{array}{l}\text { Long- } \\
\text { Term }\end{array}$ & & $\begin{array}{l}\text { Short- } \\
\text { Term }\end{array}$ & $\begin{array}{l}\text { Long. } \\
\text { Term }\end{array}$ \\
\hline 1 & PO3 & $\begin{array}{l}\text { Determine } \\
\text { technologi } \\
\text { cal } \\
\text { direction }\end{array}$ & 2 & 3 & 1 & 1 & 2 \\
\hline 2 & $\mathrm{PO} 7$ & $\begin{array}{l}\text { Manage IT } \\
\text { Human } \\
\text { resources }\end{array}$ & 2 & 3 & 1 & 1 & 2 \\
\hline 3 & PO8 & $\begin{array}{l}\text { Manage } \\
\text { guality }\end{array}$ & 2 & 3 & 1 & 1 & 2 \\
\hline 4 & Al2 & $\begin{array}{l}\text { Acquire } \\
\text { and } \\
\text { maintain } \\
\text { applicatio } \\
n \text { software }\end{array}$ & 2 & 3 & 2 & 0 & 1 \\
\hline 5 & $\mathrm{Al} 3$ & $\begin{array}{l}\text { Acquire } \\
\text { and } \\
\text { maintain } \\
\text { technology } \\
\text { infrastruct } \\
\text { ure }\end{array}$ & 2 & 3 & 2 & 0 & 1 \\
\hline 6 & $\mathrm{Al} 4$ & $\begin{array}{l}\begin{array}{l}\text { Enable } \\
\text { operation } \\
\text { and use }\end{array} \\
\text { and }\end{array}$ & 2 & 3 & 1 & 1 & 2 \\
\hline 7 & Al5 & $\begin{array}{l}\begin{array}{l}\text { Procure IT } \\
\text { resources }\end{array} \\
\text { res }\end{array}$ & 2 & 3 & 1 & 1 & 2 \\
\hline 8 & Al7 & $\begin{array}{l}\text { Install and } \\
\text { accredit } \\
\text { solutions } \\
\text { and } \\
\text { changes }\end{array}$ & 2 & 3 & 1 & 1 & 2 \\
\hline 9 & DS1 & $\begin{array}{l}\text { Define and } \\
\text { manage } \\
\text { service } \\
\text { levels }\end{array}$ & 2 & 3 & 2 & 0 & 1 \\
\hline 10 & DS2 & $\begin{array}{l}\text { Manage } \\
\text { third-party }\end{array}$ & 2 & 3 & 1 & 1 & 2 \\
\hline
\end{tabular}




\begin{tabular}{|c|c|c|c|c|c|c|c|}
\hline & & services & & & & & \\
\hline 11 & DS3 & $\begin{array}{l}\text { Manage } \\
\text { performan } \\
c e \text { and } \\
\text { capacity }\end{array}$ & 2 & 3 & 1 & 1 & 2 \\
\hline 12 & DS4 & $\begin{array}{l}\text { Ensure } \\
\text { continuous } \\
\text { service }\end{array}$ & 2 & 3 & 1 & 1 & 2 \\
\hline 13 & DS7 & 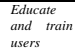 & 2 & 3 & 1 & 1 & 2 \\
\hline 14 & DS8 & $\begin{array}{l}\text { Manage } \\
\text { service } \\
\text { desk and } \\
\text { incidents }\end{array}$ & 2 & 3 & 1 & 1 & 2 \\
\hline 15 & DS9 & $\begin{array}{l}\text { Manage } \\
\text { the } \\
\text { configurati } \\
\text { on }\end{array}$ & 2 & 3 & 1 & 1 & 2 \\
\hline 16 & DS10 & $\begin{array}{l}\text { Manage } \\
\text { problems }\end{array}$ & 2 & 3 & 1 & 1 & 2 \\
\hline 17 & DS13 & $\begin{array}{l}\text { Manage } \\
\text { operations }\end{array}$ & 2 & 3 & 2 & 0 & 1 \\
\hline
\end{tabular}

Pihak manajemen UNIVERSITAS PQR harus bersedia menutupi kesenjangan / gap tingkat kematangan ini agar sumber daya TI yang dimilikinya mampu mendukung secara optimal seluruh proses bisnis UNIVERSITAS PQR dalam mencapai tujuan strategis yang telah ditetapkan berdasarkan visi dan misinya. Lebih jelasnya untuk tingkat kematangan kondisi current dan tingkat kematangan kondisi target pengelolaan TI UNIVERSITAS PQR, terlihat seperti pada Gambar 4.4.

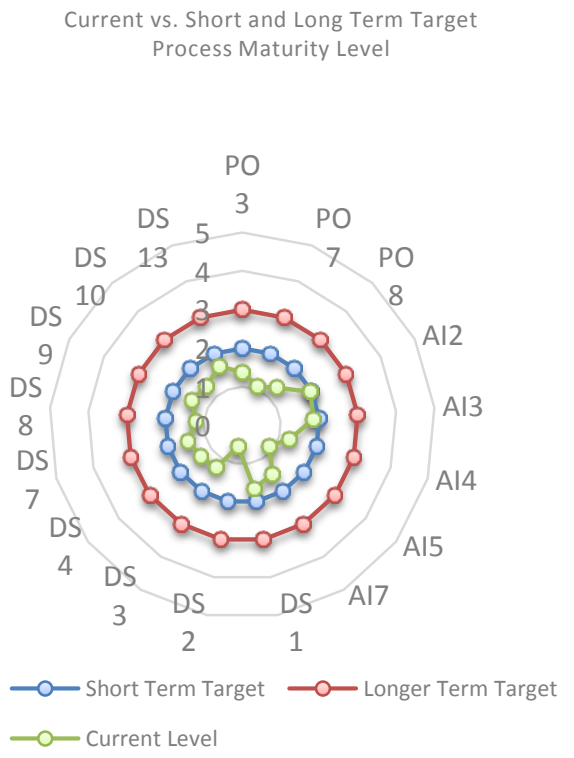

Gambar 4.4. Perbandingan Tingkat Kematangan Kondisi Current dengan Tingkat Kematangan Kondisi Target [7]

\section{IV.9.3. Identifikasi Kelemahan Kontrol Proses-proses TI Terpilih dan Analisis Dampak (Impact Analisis) terhadap Proses Bisnis UNIVERSITAS PQR}

Berdasarkan analisis tingkat kematangan proses TI terpilih pada kondisi saat ini pada tahap sebelumnya maka selanjutnya dapat dilakukan analisis yang mengindikasikan adanya kelemahan kontrol dan dampak terhadap proses bisnis organisasi/institusi berdasarkan detail control objective (DCO) setiap proses TI. Identifikasi kelemahan kontrol proses-proses TI terpilih dalam praktek belum menerapkan kontrol secara konsisten yang dapat mengancam proses bisnis 
UNIVERSITAS PQR. Sedangkan analisis dampak (Impact Analisis) terhadap proses bisnis adalah untuk mengidentifikasi akibat negatif / implikasi yang ditimbulkan akibat adanya kelemahan kontrol pada proses TI terpilih.

\section{IV.9.4. Pendefinisian Usulan Tindakan Perbaikan}

Hal yang penting dalam pendefinisian tindakan perbaikan kematangan atribut adalah bahwa proses pematangan merupakan proses perbaikan dan penyempurnaan yang secara alamiah, terus menerus dan berkelanjutan yang harus diusahakan, serta merupakan proses pembelajaran (learning curve) yang mana setiap tingkat kematangan harus ditempuh atau dilalui untuk menjadi lebih baik.

Dengan proses perbaikan secara bertahap tersebut, sehingga proses pembelajaran menuju pematangan proses-proses TI terpilih dapat dilaksanakan secara efektif dan efisien.

Mengacu pada strategi pencapaian kematangan atribut proses-proses TI terpilih, maka rekomendasi tindakan perbaikan dilakukan dalam dua tahapan, yaitu:

1. Pencapaian tingkat kematangan level 2 .

2. Pencapaian tingkat kematangan level 3.

Pada semua pencapaian tingkat kematangan atribut 2, proses pematangan atribut bergerak tumbuh dari 1 menuju 2. Penekanan pada pencapaian atribut ini adalah sisi bagaimana proses-proses dapat dilaksanakan dan berjalan meski masih intuitif, dan dibeberapa bagian telah ada pendokumentasian kebijakan, standar, dan prosedurnya.

Sedangkan pada pencapaian tingkat kematangan atribut 3, proses pematangan atribut bergerak tumbuh dari tingkat kematangan 2 menuju tingkat kematangan 3. Proses pematangan pada kelompok ini, melibatkan seluruh atribut yang meliputi Awareness and Communication, Policies, Standards and Procedures, Tools and Automation, Skill and Expertise, Responsibilities and Accountabilities, dan Goal Setting and Measurement.

\section{IV.10. Kompilasi Rekomendasi}

Dari kajian tingkat kematanga atribut diatas menunjukkan bahwa, rata-rata tingkat kematangan atribut semua proses-proses TI terpilih ada di level satu (1) dan level dua (2). Artinya bahwa proses-proses tersebut, terlebih lagi apabila dilihat dari tuntutan perspektif atribut Responsibilities and Accountabilities (RA) mempunyai tingkat kematangan atribut yang masih di bawah Baseline yaitu level tiga (3) / Defined yaitu semua proses TI telah terdefinisi dengan baik dan telah terdokumentasi.

Ini menjadi bukti bahwa saat ini terutama dilihat dari atribut responsibilities and accountabilities, TI UNIVERSITAS PQR masih bersifat repeatable but intuitif, belum ada struktur organisasi TI yang jelas dalam pelaksanaan tugas dan tanggung jawabnya. Akibat hal ini, memunculkan permasalahan lainnya yang tidak kalah pentingnya yaitu ketidakjelasan kebijakan, standar, dan prosedur yang ada didalamnya, sehingga terkadang terjadi tumpang tindih pekerjaan dalam menyelesaikan proses-proses TI yang ada. Oleh karena itu, UNIVERSITAS PQR harus bersedia mensinergikan semua sumber daya TI dan SDM TI-nya untuk menutup kelemahan tersebut. 


\section{KESIMPULAN}

Setelah melakukan analisis dan pembahasan terkait perancangan tata kelola TI di UNIVERSITAS PQR, maka dapat ditarik beberapa kesimpulan antara lain:

1. Hasil dari assessment yang telah dilakukan terkait dengan tata kelola TI UNIVERSITAS PQR saat ini, terdapat tiga (3) domain proses dalam framework COBIT 4.1 yang berhasil diidentifkasi sebagai berikut :

- Domain Plan and Organise sebanyak tiga (3) proses yaitu: Proses PO3, PO7, dan PO8.

- Domain Acquire and Implement sebanyak lima (5) proses yaitu: Proses AI2, AI3, AI4, AI5, dan AI7.

- Domain Deliver and Support sebanyak sembilan (9) proses yaitu: Proses DS1, DS2, DS3, DS4, DS7, DS8, DS9, DS10, dan DS13.

2. Dari hasil assessment yang telah dilakukan, bahwa tingkat kematangan tata kelola TI UNIVERSITAS PQR kondisi saat ini proses-proses TI terpilih sebanyak tujuh belas (17) proses secara mayoritas berada pada level satu (1) atau Ad Hoc/Initial. Rincian tingkat kematanga tersebut adalah tiga belas proses yaitu PO3, PO7, PO8, AI4, AI5, AI7, DS2, DS3, DS4, DS7, DS8, DS9, dan DS10 berada di level 1 dan empat proses yaitu AI2, AI3, DS1, dan DS13 ada di level 2.

3. Tingkat kematangan yang akan menjadi target untuk semua proses-proses TI terpilih adalah ada pada level 3. Untuk mencapai level tersebut dapat direkomendasikan beberapa hal, sebagai berikut:

- Restrukturisasi Struktur Internal Divisi IT yang ada saat ini.

- Membuat dan mendokumentasikan kebijakan dan prosedur (SOP) dalam proses tata kelola TI yang ada di UNIVERSITAS PQR.

- Pihak manajemen mengkomunikasikan secara menyeluruh di lingkungan UNIVERSITAS PQR yang tertuang dalam program awareness.

- Mengadakan pendidikan dan pelatihan terhadap SDM TI.

- Memanfaatkan standarisasi atau best practice yang telah banyak digunakan sebagai acuan dalam tata kelola TI.

\section{DAFTAR PUSTAKA}

[1] David, F. R, Strategic Management, New Jersey, Prentice Hall. 1996.

[2] IT Governance Institute, Board Briefing on IT Governance, $2^{\text {nd }}$ Edition, IT Governance Institute, 2003.

[3] IT Governance Institute, IT Governance Executive Summary, IT Governance Institute. 2003.

[4] Guritno, S, Sudaryono dan Rahardja, U, Theory and Application of IT Research (Metode Penelitian Teknologi Informasi), Andi Publishing, Yogyakarta. 2011.

[5] Universitas PQR, Rencanan Strategis Universitas PQR 2016-2020 (RENSTRA), Universitas PQR. 2015.

[6] Suryana, T, Implementasi Balanced Scorecard (BSC) Sebagai Alat Ukur Kinerja Perguruan Tinggi Studi Kasus di Univ. PQR, ICT \& Multimedia Univ. PQR. 2010.

[7] IT Governance Institute, "COBIT 4.1: Framework, Control Objectives, Management Guidelines, Maturity Models”., IT Governance Institute, 2007. 
